Editorial

\title{
Artificial intelligence - in cancer medicine all what we can say about nowadays
}

\section{Editorial}

Professor Paul Rees of Swansea University's College of Engineering who was an author of a research paper relating the results of a work conducted with his team using a machine learning to identify different kinds of cells, explains the evolution of the research: "Our project started when I took a sabbatical to go to the Broad Institute which is a part of MIT and Harvard, the project I was working on then was to take lots and lots of cell images and then measure different information about those cells". The team realized that measuring features like size of nucleus, or the cell body, how round, textured, or granular had a reference point in the field of face-recognition. "Imagine if you are trying to identify a person's face in a crowd," says Professor Rees. "What the computer program would do to measure things like how separated are the eyes? How long is the nose? How thin is the mouth?" The algorithms they would develop would work in a similar way to those for face-recognition. "So we would measure hundreds, maybe a thousand different features or properties of each cell and then we would store those into our computer."

Artificial intelligence (AI) is in the process of upserge. New techniques are producing results, which would have been unthinkable few years ago. AI is being applied for the hunt of a cure for cancer in translating scientific findings into real benefits for patients. It can screen off billions of experimental results, identify patterns and make useful predictions about diagnoses, outcomes and responses to treatment.

"So fast forward from (Jeopardy!), five years later, we're in cancer now. It's only at a few percent of its potential. I think this is a multidecade journey that we're on and we're only a few years into it" Says John Kelly, head of IBM's A.I. business unit and research labs.
Volume 8 Issue I - 2017

Hajj Adel Anis

Cedars - Jebel Ali International Hospital, UAE

Correspondence: Hajj Adel Anis, Medical Oncologist at Cedars - Jebel Ali International Hospital, 9370 Rue Lajeunesse, Montreal, UAE,Tel 438-992-55I6, Email ahajj@dr.com

Received: April 28, 2017 | Published: May 10, 2017

\section{Funding}

None.

\section{Acknowledgements}

None.

\section{Conflicts of interests}

The authors declare that there is no conflict of interest. 